УДК 378.141.4+372.881.111.1

https://doi.org/10.52058/2786-4952 -2022-1(6)-273-283

Мороз Олена Леонідівна кандидат філологічний наук, доцент, доцент кафедри англійської мови в судноводінні, Херсонська державна морська академія, просп. Ушакова 20, м. Херсон, 37000, тел.: (050) 396-06-56, https://orcid.org/0000-0002-1483-9136

\title{
НАВЧАЛЬНО-МЕТОДИЧНІ ПЕДАГОГІЧНІ УМОВИ ПІДГОТОВКИ ФАХІВЦІВ МОРСЬКОЇ ГАЛУЗІ ДО ІНШОМОВНОГО ПРОФЕСІЙНО- ОРІЕНТОВАНОГО СПІЛКУВАННЯ
}

Анотація. В статті описано навчально-методичні педагогічні умови підвищення ефективності професійно-орієнтованої іншомовної підготовки фахівців морської галузі в системі неперервної освіти. Запропоновано визначення феномена «педагогічні умови підготовки майбутніх фахівців морської галузі до професійно-орієнтованого іншомовного спілкування в системі неперервної освіти».

В статті виокремлено три базові необхідні навчально-методичні педагогічні умови підготовки майбутніх фахівців морської галузі до професійноорієнтованого іншомовного спілкування в системі неперервної освіти. Першою навчально-методичною педагогічною умовою визнається розробка інтегрованих робочих навчальних програм для кожного етапу навчання, що сприятиме послідовності, наступності та узгодженості змісту навчання i, таким чином, надають здобувачам освіти можливість переходу від однієї ступені навчання до іншої, продовження навчання на наступному ступені в іншому закладі освіти. Другою необхідною навчально-педагогічною умовою визнається розробка на основі єдиного системного підходу комплекту сучасних, якісних навчальних посібників для кожної спеціальності та рівня навчання. Пропонується опис комплекту навчальних посібників для всіх рівнів навчання здобувачів освіти морських спеціальностей. Стверджується, що найвагоміших результатів у навчальній діяльності можна досягти лише за гармонійного застосування традиційних та інформаційно-комунікаційних технологій. У зв'язку із цим, третьою навчально-методичною педагогічною умовою визнається необхідність упровадження електронного курсу дисципліни, який $є$ власним навчальним продуктом, розробленим на основі обраної закладом освіти електронної системи та програмного забезпечення. В статті пропонуються перелік єдиних вимог до створення навчально-методичного забезпечення засобами Інтернет технологій, які сприятимуть ефективності його упровадження.

Ключові слова: неперервна професійна освіта, педагогічні умови, навчальнометодичние забезпечення, морська англійська мова, професійно-орієнтовано іншомовна підготовка. 
Moroz Olena Leonidivna Candidate of Philological Sciences, $\mathrm{PhD}$, Associate Professor of the English Language Department for Deck Officers, Kherson State Maritime Academy, Ushakova Ave., 20, Kherson, 37000, tel.: (050) 396-06-56, https://orcid.org/0000-0002-1483-9136

\title{
LEARNING AND TEACHING PEDAGOGICAL CONDITIONS OF SEAFARERS' PROFESSIONALLY-ORIENTEDFOREIGN FOREIGN LANGUAGE TRAINING
}

\begin{abstract}
The article substantiates learning and teaching pedagogical conditions of seafarers' professionally-oriented foreign language training efficiency improvement in the framework of continuous education. It is suggested how to define the phenomenon of "pedagogical conditions of future seafarers professionally-oriented foreign language training in the framework of continuous education».

There are three basic compulsory learning and teaching pedagogical conditions of seafarers' professionally-oriented foreign language training specified in the article. The first learning and teaching pedagogical condition is declared to be the development of the integrated course curricula for each stage of continuous professional training which enables the succession, continuity and coordination of the discipline content and thus allows the students for the possibility to transfer the education stages, to continue their professional training at the next stage in the other type of the educational establishment. It is stated that the second learning and teaching pedagogical condition is the development of the up-to-date, efficient student books sets for each specialization and stage of professional training. This process is recommended to be carried out on the basis of the unified system approach. The article provides for the description of the student books set for all levels of education for maritime students/cadets of different specializations. It is claimed that the best results in the professional training can be obtained only under the condition of the well-balanced combination of both traditional and information and communication technologies. That is why, the third learning and teaching pedagogical condition suggested in the paper is the requirement to introduce into practice the application of the electronic Maritime English course. It is proved that the electronic course is going to be more efficient if it is tailor made product developed by the teachers on the basis of the digital system and software chosen by the educational establishment. The paper suggests the list of requirements to be met when developing teaching and learning support materials kit by means of the Internet technologies which will allow for the improvement of its efficiency.
\end{abstract}

Key words: continuous professional education, pedagogical conditions, learning and teaching materials, Maritime English, professionally-oriented foreign language training.

Постановка проблеми. Ефективна реалізація освітньої інновації можлива лише за умови ретельного всебічного аналізу, усвідомлення й осмислення 
умов, за яких упровадження та функціонування системи неперервної освіти стало б можливим, доцільним та успішним. Широкий діапазон актуальних проблем, пов'язаних з удосконаленням освітньої галузі, конкретні потреби навчальних закладів і відповідні цілі педагогічних досліджень зумовлюють різноманітність підходів до трактування педагогічних умов, проте одностайного визначення цього поняття в науковій літературі немає [1, С. 252]. 3 огляду на особливості перебігу педагогічного процесу, специфіки певного освітнього середовища, що знаходиться в центрі уваги дослідників, в науковопедагогічних джерелах запропоновано та обгрунтовано різні підходи до класифікації та типологізації педагогічних умов. Грунтовний аналіз науковопедагогічної літератури уможливлює висновок про те, що існують загальні, базові чинники, що можна вважати передумовами ефективної реалізації освітнього процесу загалом. Проте, наявність обгрунтованих різних підходів до класифікації педагогічних умов, виокремлення їх різних типів у відповідності до сфер реалізації, а також аспектів освітньої діяльності, свідчить про необхідність виокремлення специфічних педагогічних умов, спрямованих на вдосконалення й інтенсифікацію навчально-пізнавального, навчально-виховного, організаційно-управлінського та інших складників процесу професійної підготовки кожного окремого напряму.

Аналіз досліджень і публікацій. У науковому доробку сутність поняття «педагогічні умови» розглядається переважно у зв'язку 3 оптимізацією освітнього процесу (Ю. Бабанський, О. Бережнова, Р. Гуревич, В. Манько, В. Нікіфоров, О. Суригін, О. Пєхота, С. Яковлєв та Н. Яковлєва) та його цілісністю й системністю (І. Підласий).А.Алексюк та П. Підкасистий розглядають педагогічні умови як обставини, що відображають вимоги до навчального процесу, дотримання яких забезпечує цілеспрямований вплив на його результат; як систему певних форм, методів, матеріальних засобів, обставин, чинників, що впливають на процес досягнення мети [2]. У працях В. Бойчука, А. Литвина підкреслюється, що педагогічні умови спрямовуються на потреби суб'єктів освітнього процесу та відображають можливості освітнього середовища та його впливу на педагогічну взаємодію; $є$ складним елементом цілісного педагогічного процесу, активними учасниками якого є всі його суб'єкти; становлять основу для особистісного розвитку суб'єктів навчання [1;3].

Для мети нашого дослідження особливого значення набувають наукові дослідження специфіки організації процесу підготовки до професійноорієнтованої (іншомовної) комунікації: визначення організаційно-педагогічних засад, які покликані забезпечити формування іншомовної соціокультурної компетенції студентів нефілологічних спеціальностей (Р. Гришкова), характеристика особливостей процесу формування професійного мовлення у майбутніх фахівців авіаційної галузі (О. Ковтун), визначення педагогічних умов професійно-орієнтованого навчання іноземних мов майбутніх фахівців економічного профілю (К. Вишневська), характеристика формування 
Журнал«Герспективитаіновації наукиљ

(Серія«Гедагогіка», Серія«Гтихологія», Серія«Медицинв»

№1(6) 2022

комунікативної компетенції фахівців митної служби (О. Павленко), визначення педагогічних умов підготовки майбутніх судноводіїв до професійно-орієнтованого спілкування (В. Смелікова), характеристика формування готовності інженерів-судномеханіків до міжкультурної комунікації (М. Сотер) тощо.

Аналіз науково-педагогічних джерел із проблеми нашого дослідження, власний багаторічний досвід викладання морської англійської мови дозволили зробити висновок про необхідність створення для продуктивної підготовки курсантів до професійно-орієнтованої іншомовної комунікації на кожному освітньо-кваліфікаційному рівні відповідних педагогічних умов, які б уможливили ефективну реалізацію педагогічної концепції формування іншомовної професійно-орієнтованої компетенції спеціалістів морського флоту в системі неперервної освіти. Вважаємо, що педагогічні умови повинні стосуватися кожного із компонентів освітнього процесу: змісту навчання; форм, засобів, методів і технологій; проектування, організації та управління освітнім процесом. Тому пропонуємо виділяти у системі педагогічних умов підготовки майбутніх фахівців морської галузі до професійно-орієнтованого іншомовного спілкування в системі неперервної освіти три базові групи: 1) навчальнометодичні; 2) організаційно-методичні; 3) процесуально-методичні.

Серед ключових педагогічних умов, які покликані забезпечити якісну професійно-орієнтовану іншомовну підготовку майбутніх фахівців морської галузі виокремлюємо навчально-методичний супровід дисципліни «Морська англійська мова», як такий, що безпосередньо впливає на змістовий компонент освітнього процесу та сприяє досягнення його ефективності, адже вважаємо, що саме від належного відбору змісту навчання 3 дисципліни залежатиме відповідність фахової підготовки здобувача вищої освіти базовим вимогам роботодавців, а отже i їх конкурентоспроможність на ринку праці. Тому, метою статті $\epsilon$ уточнення поняття педагогічні умови підготовки майбутніх фахівців морської галузі до професійно-орієнтованого іншомовного спілкування в системі неперервної освіти та визначення ключових навчальнометодичних педагогічний умов підвищення ефективності процесу формування професійно-орієнтованої комунікативної компетенції.

Виклад основного матеріалу. Педагогічні умови - це свідомо спроектовані та реалізовані системотвірні чинники, що впливають на зовнішні та внутрішні обставини освітнього процесу, забезпечуючи цілісність навчання й виховання відповідно до вимог суспільства та стандартів освіти, підвищуючи ефективність освітнього процесу, уможливлюючи реалізацію певних інновацій та ефективний перебіг їх втілення [1, С. 252-253]. Під педагогічними умовами підготовки майбутніх фахівців морської галузі до професійно-орієнтованого іншомовного спілкування в системі неперервної освіти розуміємо такий комплекс педагогічних заходів та обставин, який забезпечить підвищення якості процесу формування та розвитку професійноорієнтованої комунікативної компетенції на основі реалізації сучасної 
компетентнісної, особистісно-орієнтованої парадигми неперервної освіти i, таким чином, уможливить підготовку конкурентоздатних фахівців для судноплавної галузі.

Навчально-методичні педагогічні умови формування професійноорієнтованої комунікативної компетенції безпосередньо пов’язані із розробкою та впровадженням якісного навчально-методичного забезпечення дисципліни. В нашому дослідженні виокремлюємо три базові необхідні навчально-методичні педагогічні умови підготовки майбутніх фахівців морської галузі до професійно-орієнтованого іншомовного спілкування в системі неперервної освіти.

Основою для оновлення змісту освіти у вищій школі мають стати моделі відповідної професійної діяльності, кваліфікаційні характеристики фахівців [4, С. 408] та вимоги працедавців. Тобто, однією з важливих педагогічних умов підготовки майбутніх фахівців морської галузі до професійно-орієнтованого іншомовного спілкування в системі неперервної освіти $\epsilon$ розробка інтегрованих робочих навчальних програм 3 дисципліни «Морська англійська мова». Стверджуємо, що формування змісту навчальної програми 3 дисципліни «Морська англійська мова» необхідно забезпечувати реалізацію чотирьох базових дидактичних принципи: принцип узгодженості, принцип ранньої професійної спрямованості, принцип наступності, принцип послідовності. Принцип узгодженості при відборі змісту програми «Морська англійська мова» передбачає урахування навчальних планів факультету 3 метою обрання та визначення логічної послідовності тематики навчальних занять у відповідності тим професійно-орієнтованим дисциплінам, що викладаються на кожному курсі. Принцип ранньої професійної спрямованості передбачає відбір для вивчення тем професійно-спрямованого змісту за обраним студентами фахом 3 першого року навчання, що сприяє інтеграції фахових знань у сферу іншомовного спілкування, забезпечує особливу мотивацію до навчання. Принципи наступності та послідовності забезпечують функціонування системи неперервної освіти, оскільки уможливлюють визначення та узгодженість змісту навчання для кожного етапу навчання i, таким чином, надають здобувачам освіти можливість переходу від однієї ступені навчання до іншої, продовження навчання на наступному ступені в іншому закладі.

Однак, при впровадженні програм нового типу важливо відповідним чином доукомплектувати фонд підручників і навчальних посібників, що мають враховувати специфіку професійної спрямованості іноземної мови, зміну методик викладання і ролі викладача, який більше виступає в ролі організатора процесу і консультанта.

Проведений аналіз існуючих підручників для англійської мови професійного спрямування уможливив висновок про те, що майже усі опубліковані в Україні підручники та посібники мають цілий ряд недоліків та не задовольняють потреб тих, хто навчається. Перш за все, проблема полягає в 
Журнал«Герспективитаіновації наукиљ

(Серія«Гедагогіка», Серія«ГЕихологія», Серія«Медицинв»

№1(6) 2022

тому, що існуючі підручники не враховують особливостей конкретної спеціалізації, а тому не можуть вважатися професійно-орієнтованими, адже не дають змоги практикувати та вдосконалювати комунікативні вміння у специфічних професійно-значущих ситуаціях, тобто потреби студентів не враховуються. По-друге, існуючі підручники та посібники здебільшого побудовані на структурно-граматичному підході, а отже не сприяють розвитку чотирьох базових комунікативних макро-умінь, оскільки в них бракує комунікативних вправ. А отже, формування єдиного системного підходу до розробки навчально-методичного комплекту дисципліни «Морська англійська мова» в усіх навчальних закладах науково-педагогічно-виробничого комплексу 3 метою забезпечення якісного формування професійно-оріснтованої комунікативної компетенції майбутніх фахівців морської галузі в системі неперервної освіти та створення комплекту сучасних, якісних навчальних посібників для кожної спеціальності та рівня навчання є другою навчальнометодичною педагогічною умовою підвищення якості професійно-орієнтованої іншомовної підготовки.

Вивчивши обгрунтовані теоретичні засади та вимоги до підручника іноземної мови (Н. О. Бражник, С. В. Гапонова, С. П. Кожушко, С. Ю. Ніколаєва, В. Г. Редько, Л. А. Сажко, О. Б. Тарнопольський та інші), дійшли висновку, що засади створення підручників іноземної мови для студентів нефілологічних спеціальностей (політологів, екологів, юристів, економістів) розроблені та висвітлені в науковій літературі лише частково. Що ж до морських спеціальностей, то ані вдалих навчальних посібників або підручників, ані практичних порад щодо створення ресурсного банку навчальних матеріалів на сьогодні не має.

Головними вимогами, яким мають відповідати створювані навчальні засоби (в тому числі, й навчальні підручники та посібники), є їх орієнтованість на розвиток особистості майбутнього фахівця, а значить відповідність результатів комунікативної підготовки майбутніх мореплавців вимогам сфери їхньої професійної діяльності і, таким чином, забезпечення їх конкурентоздатності. Виступаючи матеріальним засобом навчання, підручник або посібник повинен оптимально забезпечувати реалізацію різноманітних видів навчальної діяльності, до якої залучаються всі студенти (фронтальна робота), групи студентів (групова робота), окремі студенти (індивідуальна робота) для ознайомлення, вивчення, закріплення, повторення, узагальнення навчального матеріалу. Кожна вправа у посібнику або підручнику повинна бути орієнтованою на цілі навчання, тобто сприяти досягненню поставлених цілей, а значить забезпечувати реалізацію комунікативно-компетентнісного підходу та новітніх технологій навчання іноземної мови. Крім того, посібники та підручники мають бути побудовані таким чином, щоб надати можливість студентам/курсантам використовувати їх як засіб самостійної навчальної діяльності.

У своєму дослідженні педагогічних засад формування іншомовної соціокультурної компетенції студентів нефілологічних спеціальностей 
Р. Гришкова стверджує, що «дуже часто програма вивчення іноземної мови складається викладачем на основі змісту матеріалу підручника, яким будуть послуговуватись студенти в процесі навчання мови» [5, С. 134]. Проте, ми вважаємо, що ефективна професійно-орієнтовано іншомовна підготовка майбутніх фахівців (незалежно від профілю та спеціалізації) можлива лише за умови розробки якісної робочої навчальної програми, яка б відповідала усім вимогам професійної сфери до компетентності фахівця, а вже потім підготовки на іï основі необхідних навчальних матеріалів для досягнення навчальних цілей, сформульованих у програмі.

В науково-педагогічному комплексі «Херсонська морська державна академія» авторським колективом викладачів кафедри англійської мови розроблено комплект навчальних посібників для всіх рівнів навчання. Студенти/курсанти, що здобувають кваліфікацію першого (допоміжного) рівня експлуатації - молодший рядовий плавсклад - мають опанувати однакові комунікативні уміння, що стосуються базових знань $з$ устрою судна, правил поведінки у надзвичайних ситуаціях, назв та розташування рятувального та протипожежного обладнання тощо, незалежно від спеціальності. А тому, протягом навчання у Професійному морському ліцеї, перших двох курсів у Фаховому морському коледжі та перших трьох семестрів навчання в академії, студенти/курсанти вивчають Загальну морську англійську. Після цього, для кожної спеціальності розробляються окремі навчальні посібники зі Спеціалізованої морської англійської. Проте, базові вимоги до розробки навчальних матеріалів $є$ єдиними для всіх кафедр усіх структурних підрозділів комплексу, що забезпечує єдність, системність, наступність та послідовність процесу вивчення морської англійської мови на всіх етапах навчання, легку адаптацію студентів/курсантів до процесу професійно-орієнтованої іншомовної комунікативної підготовки при переході з одного етапу навчання на інший. Ці базові вимоги обговорюються та затверджують на Координаційній Раді та є обов'язковими для всіх розробників навчальних посібників.

Кожен окремий навчальний посібник розрахований на 1 семестр навчання. Зміст навчального курсу розподілено на змістовні модулі, які включають в себе логічно завершену одиницю навчального матеріалу, що забезпечує досягнення поставлених цілей. На початку кожного модуля обов'язково зазначаються ключова компетенція (essential competency), тобто уміння, яке студенти/курсанти повинні демонструвати по завершенню модуля, а також вказується уміння до кожної частини модуля (зазвичай кожен модуль містить три частини (Parts)). Наприклад, перший модуль навчального посібника While Ashore (для 1 семестру навчання) Maritime Education має на меті наступні навчальні цілі:

\section{You will be able to:}

1. ask for and give personal data

2. describe seafarer training and education 
Журнал«Герспективитаінновації наукиљ

(Серія «Гедагогіка», Серія«ГЕихологія», Серія«Медицина»

№1(6) 2022

3. discuss typical activities in the Academy and leisure activities

Essential competency: describe seafarer training and education [6, C. 7].

Секція You will be able to (Ви зможете) зазначає ті уміння, що зможуть демонструвати студенти/курсанти по завершенню вивчення кожної окремої частини модуля (iх три, а, отже, і умінь визначено три), а секція Essential competency містить інформацію про ключову компетенцію, які демонструватимуть студенти/курсанти по завершенню вивчення модуля та яка відповідає вимогам ПДНВ і вказана у робочій навчальній програмі.

Усі навчальні посібники чітко структуровані, мають поурочну структуру для забезпечення орієнтації не тільки в змісті, а й у послідовності викладення матеріалу. Кожне окреме тематичне заняття побудовано за структурою, що відповідає певному етапу навчання: 1 етап (допоміжний рівень) - РPР (Presentation, Practice, Production); 2 етап (операційний рівень) - EASA (Engage, Activate, Study, Activate); 3 етап (управлінський) - Patchwork lesson design.

Кожне тематичне заняття фокусується на презентації певної кількості лексичних одиниць, важливих для вивчення теми, або ж певного граматичного явища. Навчальний матеріал кожного заняття, що обов'язково є комунікативно спрямованим, забезпечує необхідну кількість контрольованих, напівконтрольованих та «вільних» вправ для затренування та використання вивченого мовного матеріалу у проблемних професійно значущих комунікативних ситуаціях. Навчальні посібники містять автентичні матеріали, запозичені із англомовних спеціалізованих морських сайтів, на які автори обов'язково залишають посилання. Тексти для читання, згідно вимог комунікативного підходу, не призначені ані для перекладу, ані для переказу, а слугують базою для висловлення власних думок того, хто вчиться, сприяючи розвитку спонтанного мовлення та формуючи навички критичного мислення студентів/курсантів. Кожний змістовний модуль завершується питаннями для самоперевірки та містить словник активної лексики до модуля.

Ми погоджуємося із твердженням Р. Гришкової про те, що роботу 3 підручником на занятті не треба абсолютизувати. Навіть найсучасніший та найвдаліший навчальний посібник або підручник є лише допоміжним засобом у засвоєнні змісту навчання, оскільки ми вивчаємо живу іноземну мову, а не підручник [5, С. 306]. Крім того, у підручнику неможливо подати всі методично доцільні й організовані відповідно до дидактичних умов вправи для вивчення кожної лексичної одиниці і кожного граматичного явища або для формування вмінь у різних видах мовленнєвої діяльності.

Зважаючи на той факт, що для якісного оволодіння навчальним матеріалом та для формування тих чи інших навичок різним студентам/курсантам необхідна різна кількість вправ, а навчальний посібник не може містити їх нескінченну кількість, вважаємо за доцільне упроваджсення електронного курсу дисципліни, який доповнить навчальнометодичний комплекс та уможливить підвищення ефективності професійно- 
орієнтованої іншомовної підготовки за рахунок індивідуалізації процесу навчання. В. Кремень слушно зауважує, що «Державні стандарти, навчальні програми, підручники і засоби навчання, якими б досконалими вони не були, це лише необхідна, але недостатня умова для підвищення якості освіти. Теорія й практика свідчать, що найвагоміших результатів у навчальній діяльності можна досягти лише за гармонійного застосування різних методів, форм i засобів навчання, у тому числі й інформаційно-комунікаційних технологій» $[7$, С. 8]. Погоджуємося із твердженням I. Секрет про те, що організація навчальної діяльності усіх категорій студентства у відповідності до індивідуальних можливостей кожного з метою компенсації недоліку необхідних знань, умінь та навичок користування іноземною мовою у професійно-зорієнтованих ситуаціях можлива за умови застосування засобів дистанційної освіти [8, С. 279] або за умови створення адекватного інформаційного освітнього середовища професійної підготовки. Створення інформаційного освітнього середовища потребує розроблення відповідного інформаційного ресурсу, який уможливить використання засобів дистанційної освіти у відповідності до певних дидактичних принципів та засад, визначення основних напрямів цілеспрямованої різноманітної освітньої діяльності студентів, в яких застосування засобів дистанційної освіти сприятиме підвищенню якості їх навчання, розширенню можливостей вивчення чи ознайомлення 3 матеріалом, економії зусиль у підготовці до занять тощо [8, С. 280].

Оскільки наразі існує розмаїття електронного навчального забезпечення 3 іноземних мов загального вжитку, проте наявність таких ресурсів для вивчення іноземної мови професійного спрямування обмежена, то вважаємо за доцільне серед важливих навчально-методичних педагогічних умов підготовки майбутніх фахівців морської галузі до професійно-орієнтованого іншомовного спілкування в системі неперервної освіти виокремлювати й створення власних навчальних продуктів засобами єдиної, обраної для всіх структурних підрозділів електронної системи та програмного забезпечення. Важливим чинником, який визначатиме ефективність використання електронного навчального курсу в рамках науково-педагогічного комплексу та сприятиме реалізації концепції неперервної професійної освіти мореплавців є дотримання усіма членами викладацького колективу єдиних вимог до створення навчально-методичного забезпечення засобами Інтернет технологій. До таких вимог пропонуємо відносити наступні:

1) змістовне наповнення навчальних матеріалів електронного курсу повинно бути обумовлене змістом навчальної дисципліни та навчальними цілями, визначеними робочою навчальною програмою, а отже всі пропоновані матеріали та завдання повинні бути професійно спрямованими та відповідати специфічним аспектам професійної діяльності певної спеціальності;

2) наряду із суто мовними вправами на розвиток та вдосконалення лінгвістичного компоненту ПОКК серед матеріалів електронного курсу обов'язково мають бути присутні комунікативні завдання творчого та проблемного характеру на розвиток та вдосконалення когнітивного та 
стратегічного іiі компонентів, що можливо за умови використання різних режимів навчальної діяльності - від індивідуальної до групової - у їі різних формах;

3) електронний курс повинен бути технічно доступним для організації як аудиторної, та i самостійної роботи здобувачів освіти, бути зручним у застосуванні, повним та послідовним у формуванні навичок та компетентностей 3 усіх видів іншомовної комунікативної діяльності;

4) розміщувані в рамках курсу інформаційні матеріали мають бути прикладом автентичного неадаптованого контекстного (професійно значущого) мовлення 3 метою підвищення мотивації та пізнавального інтересу здобувачів освіти.

Зазначені базові вимоги розроблено на засіданнях робочої групи, до складу якої входять представники усіх кафедр англійської мови комплексу, а також розроблено та затверджено на Координаційній Раді вимоги щодо базової структури курсу. Проте, було зазначено, що кожен викладач також має право на творчий підхід до організації власного електронного навчального курсу. В ході дослідження виявилося, що таке творче створення навчальних матеріалів кожним викладачем для конкретної групи $\epsilon$ найбільш продуктивним способом застосування інформаційних технологій у формуванні ПОКК фахівців морської галузі, оскільки уможливлює високий рівень індивідуалізації та студентоцентрованості, а можливість обміну матеріалами між викладачами, обговорення контенту вході та після завершення курсу дозволяє критично його оцінити та вдосконалювати.

Висновки. Таким чином, стверджуємо, що використання цілісного системно організованого комплексу навчально-методичного забезпечення дисципліни «Морська англійська мова», який інтегративно поєднує різні методи і форми навчальної діяльності, $\epsilon$ необхідною групою навчальнометодичних педагогічних умов підвищення ефективності іншомовної професійно-орієнтованої підготовки фахівців морської галузі. Реалізація визначених навчально-методичних умов забезпечує високу якість викладання і вивчення іноземної мови професійного спрямування на кожному етапі ступеневого навчання, сприяє розвитку позитивної мотивації та успішному формуванню професійно-орієнтованої комунікативної компетентності майбутніх мореплавців.

Подальшою перспективою дослідження $\epsilon$ обгрунтування переліку організаційно-методичних та процесуально-методичних педагогічних умов, які сприятимуть забезпеченню ефективності організації освітнього процесу та встановленню й застосуванню найефективніших форм, методів, прийомів та технологій навчання іноземної мови професійного спрямування.

\section{Лimepamypa:}

1. Бойчук В. М. Теоретичні і методичні основи художньо-графічної підготовки майбутнього вчителя технологій : дис. ... д-ра пед. наук : 13.00.04. Київ, 2016. 873c.

2. Організація самостійної роботи студентів в умовах інтенсифікації навчання : навч. посіб / А. М. Алексюк та ін. Київ : ІСДО, 1993. 336 с. 
3. Литвин А. В. Методологічні засади поняття «педагогічні умови» : на допомогу здобувачам наукового ступеня. Львів : СПОЛОМ, 2014. 76 с.

4. Алексюк А. М. Педагогіка вищої освіти України. Історія. Теорія. Київ : Либідь, 1998. 560c.

5. Гришкова Р. О. Педагогічні засади формування іншомовної соціокультурної компетенції студентів нефілологічних спеціальностей у процесі фахової підготовки : дис. ... д-ра пед. наук : 13.00.04. Київ, 2007. 446 с.

6. While Ashore : coursebook / A. Vid, O. Frolova, V. Kudryavtseva, O. Moroz, I. Shvetsova. Kherson : Science Park "Maritime Industry Innovations” Ltd., 2021. 250 p.

7. Кремень В. Г. Модернізація освіти на новому етапі інформатизації. Інформаційнотелекомунікаційні технології в сучасній освіті : досвід, проблеми, перспективи : матеріали третьої міжнар. наук.-практ. конф., м. Львів, 12-14 листоп. 2012 р., Львів. С. 3-8.

8. Секрет I. В. Теоретичні та методичні основи формування іншомовної професійної компетентності студентів вищих технічних навчальних закладів в умовах дистанційної освіти : дис. ... д-ра пед. наук: 13.00.04. Київ, 2012. 552 с.

\section{References:}

1. Boichuk, V. M. (2016). Teoretychni i metodychni osnovy khudozhno-hrafichnoi pidhotovky maibutnoho vchytelia tekhnolohii [Theoretical and Methodological Basics of Art-graphical Preparation of Future Technology Teachers]. Doctor's Thesis. Kyiv: Natsionalna akademiia pedahohichnykh nauk Ukrainy instytut pedahohichnoi osvity i osvity doroslykh [in Ukrainian].

2. Aleksiuk, A. M. (1993). Orhanizatsiia samostiinoi roboty studentiv $v$ umovakh intensyfikatsii navchannia [The organization of the individual work of students under the conditions of the education intensification]. Kyiv : ISDO [in Ukrainian].

3. Lytvyn, A. V. (2014). Metodolohichni zasady poniattia «pedahohichni umovy» : na dopomohu zdobuvacham naukovoho stupenia [Methodological grounds of the phenomenon "pedagogical conditions" : to assist the postgraduate degree seeker]. Lviv : SPOLOM [in Ukrainian].

4. Aleksiuk, A. M. (1998). Pedahohika vyshchoi osvity Ukrainy. Istoriia. Teoriia. [Pedagogics of Higher Education in Ukraine. Theory. History]. Kyiv : Lybid [in Ukrainian].

5. Hryshkova, R.O. (2007). Pedahohichni zasady formuvannia inshomovnoi sotsiokulturnoi kompetentsii studentiv nefilolohichnykh spetsialnostei u protsesi fakhovoi pidhotovky [Pedagogical grounds of foreign sociocultural competency formation of non-philological students in the process of professional training]. Doctor's Thesis. Kyiv : Institute of Higher Education NAES of Ukraine [in Ukrainian].

6. Vid, A., Frolova, O., Kudryavtseva, V., Moroz, O., \& Shvetsova, I. (2021). While Ashore: coursebook. Kherson : Science Park "Maritime Industry Innovations" Ltd. [in English].

7. Kremen, V. H. (2012) Modernizatsiia osvity na novomu etapi informatyzatsii [Education modernization at the new stage of informatization]. Proceedings from: III Mizhnarodnoi naukovopraktychnoi konferentsii : Informatsiino-telekomunikatsiini tekhnolohii v suchasnii osviti : dosvid, problemy, perspektyvy - The Third Scientific and Practical Conference "Information and Telecommunication Technologies in Modern Education: Experience, Problems, Perspectives". (pp. 3-8). Lviv. [in Ukrainian].

8. Sekret, I. V. (2012). Teoretychni ta metodychni osnovy formuvannia inshomovnoi profesiinoi kompetentnosti studentiv vyshchykh tekhnichnykh navchalnykh zakladiv $\mathrm{v}$ umovakh dystantsiinoi osvity [Theoretical and methodological basis of foreign language professional competency formation of the higher educational establishments students in terms of distant learning]. Doctor's Thesis. Kyiv : Dniprovsky State Technical University [in Ukrainian]. 